\title{
Analisis Kesalahan Mahasiswa Semester Pertama Dalam Menentukan Nilai Fungsi Trigonometri Sudut Kuadran
}

\author{
Yayan Eryk Setiawan ${ }^{1}$ \\ ${ }^{1}$ Program Studi Pendidikan Matematika, Fakultas Keguruan dan Ilmu Pendidikan, Universitas Islam Malang, \\ Jl. MT Haryono 193, Kota Malang, Jawa Timur, Indonesia \\ yayaneryksetiawan@unisma.ac.id
}

\begin{abstract}
One of the important materials for students to learn is the value of the quadrant angle trigonometric function. However, some first semester students still found errors in determining the value of the quadrant angle trigonometric function. These student errors are important for further analysis. The purpose of this study was to describe the mistakes of the first semester students in determining the value of the quadrant angle trigonometric function. This research method is descriptive qualitative research with a case study approach to 6 students as the subject of this research. The research instrument consisted of two questions about the value of the quadrant trigonometric function. The data collected in this study consisted of the subject's work and transcripts of interviews with the subject. The results of the subject's work were analyzed to know the types of errors the subject had made, while the interview transcripts were analyzed to determine the factors causing the errors made by the subject. The results showed that there were three mistakes of students in determining the value of the quadrant angle trigonometric function, namely principle's errors, miscalculation, and factual errors. The principle's errors are due to only using intuitive thinking. Miscalculation due to misunderstanding. Fact errors caused by inaccuracy. The results of this study contributed to correcting student misunderstandings in determining the value of the quadrant angle trigonometric function.
\end{abstract}

Keywords: Trigonometry, Quadrant Angle, Principle’s Error, Miscalculation, Factual Error

\begin{abstract}
Abstrak
Salah satu materi yang penting untuk dipelajari oleh mahasiswa adalah nilai fungsi trigonometri sudut kuadran. Akan tetapi masih ditemukan beberapa mahasiswa semester pertama mengalami kesalahan dalam menentukan nilai fungsi trigonometri sudut kuadran. Kesalahan-kesalahan mahasiswa ini penting untuk dianalisis lebih lanjut. Tujuan penelitian ini adalah untuk mendeskripsikan kesalahan-kesalahan mahasiswa semester pertama dalam menentukan nilai fungsi trigonometri sudut kuadran. Metode penelitian ini adalah penelitian deskriptif kualitatif dengan pendekatan studi kasus terhadap 6 mahasiswa sebagi subjek penelitian ini. Instrumen penelitian ini terdiri dari dua soal tentang nilai fungsi trigonometri sudut kuadran. Data yang dikumpulkan dalam penelitian ini terdiri dari hasil pekerjaan subjek dan transkrip hasil wawancara dengan subjek. Hasil pekerjaan subjek dianalisis dengan tujuan untuk mengetahui jenis kesalahan yang dilakukan subjek, sedangkan transkrip wawancara dianalisis dengan tujuan untuk mengetahui faktor-faktor penyebab kesalahan yang dilakukan oleh subjek. Hasil penelitian menunjukkan bahwa terdapat tiga kesalahan mahasiswa dalam menentukan nilai fungsi trigonometri sudut kuadran, yaitu kesalahan prinsip, kesalahan hitung, dan kesalahan fakta. Kesalahan prinsip dikarenakan hanya menggunakan pemikiran intuitif. Kesalahan hitung dikarenakan kesalahpahaman. Kesalahan fakta disebabkan kurang teliti. Hasil penelitian ini berkonstribusi untuk memperbaiki kesalahpahaman mahasiswa dalam menentukan nilai fungsi trigonometri sudut kuadran.
\end{abstract}

Kata kunci: Trigonometri, Sudut Kuadran, Kesalahan Prinsip, Kesalahan Hitung, Kesalahan Fakta

Copyright (c) 2021 Yayan Eryk Setiawan

$\triangle$ Corresponding author: Yayan Eryk Setiawan

Email Address: yayaneriksetiawan@unisma.ac.id (Jl. MT. Haryono 193, Kota Malang, Jawa Timur)

Received 15 Desember 2021, Accepted 15 Februari 2021, Published 04 Maret 2021

\section{PENDAHULUAN}

Trigonometri merupakan cabang ilmu matematika yang secara umum membahas mengenai segitiga (Downing, 2009) dan secara khusus membahas mengenai fungsi trigonometri (Lial, Hornsby, 
Schneider, \& Daniels, 2016). Sebagai cabang ilmu matematika, trigonometri dalam perguruan tinggi dibahas secara khusus dalam mata kuliah Trigonometri. Mata kuliah trigonometri ini merupakan mata kuliah wajib yang harus ditempuh oleh mahasiswa program studi pendidikan matematika. Pentingnya mata kuliah trigonometri ini untuk ditempuh oleh mahasiswa dikarenakan materi trigonometri ini diberikan pada jenjang sekolah menengah atas, sehingga mahasiswa calon guru harus menguasai materi-materi yang ada dalam mata kuliah trigonometri. Selain itu, materi dalam mata kuliah trigonometri ini banyak berhubungan dengan konsep dan aplikasinya dalam berbagai disiplin ilmu (Nabie, Akayuure, Ibrahim-Bariham, \& Sofo, 2018). Tidak hanya itu, mata kuliah trigonometri ini merupakan materi prasyarat untuk mata kuliah kalkulus, analisis vektor, dan persamaan diferensial. Jadi dapat dikatakan bahwa mata kuliah trigonometri ini penting untuk dikuasasi oleh mahasiswa calon guru, guna sebagai bekal untuk membelajarkan materi trigonometri di jenjang sekolah memengah atas.

Salah satu materi yang dibahas dalam mata kuliah trigonometri adalah nilai fungsi trigonometri sudut kuadran. Sudut kuadran didefinisikan sebagai sudut yang sisi terminalnya dalam posisi standar terletak di sepanjang sumbu $y$ atau sepanjang sumbu $x$ (Downing, 2009; Lial et al., 2016). Misalnya sudut $90^{\circ}$ yang memiliki sisi awal pada posisi standar adalah sumbu $x$ positif dan memiliki sisi terminal pada sumbu $y$ positif, maka sudut $90^{\circ}$ ini termasuk sudut kuadran. Selain itu ada beberapa sudut kuadran lainnya, misal: $0^{0}, 180^{\circ}, 270^{\circ}, 360^{\circ}, 450^{\circ},-90^{\circ},-180^{\circ},-270^{\circ}$ dan sebagainya. Sudut-sudut kuadran ini dipelajari secara khusus dengan menerapkan perbandingan trigonometri segitiga. Misalnya, nilai dari $\sin 270^{\circ}=-1$. Karena $270^{\circ}$ merupakan sudut kuadran, maka kita bisa melihat sisi terminalnya, yaitu berada pada sumbu $y$ negatif. Ini artinya, nilai $x=0$, $y=-1$ dan $r=1$. Perbandingan trigonometri dari fungsi sin adalah SINDEMI (sin depan miring) atau dalam posisi standar adalah $\sin \theta=\frac{y}{r}$. Jadi diperoleh $\sin 270^{\circ}=\frac{y}{r}=\frac{-1}{1}=-1$. Materi nilai fungsi trigonometri sudut kuadran ini penting untuk dipelajari, karena digunakan sebagai dasar untuk menentukan nilai fungsi trigonometri sudut yang lebih dari $360^{\circ}$ dan juga sudut negatif.

Hasil penelitian pendahuluan menunjukkan bahwa dari 82 mahasiswa semester pertama yang menyelesaikan soal tentang fungsi trigonometri sudut kuadran diperoleh 42 mahasiswa berhasil menyelesaikan soal dan 40 mahasiswa mengalami kesalahan dalam menyelesaikan soal yang melibatkan nilai fungsi trigonometri sudut kuadran. Ini artinya terdapat $49 \%$ mahasiswa yang mengalami kesalahan dalam menentukan nilai fungsi trigonometri sudut kuadran. Kesalahankesalahan mmahasiswa dalam menentukan nilai fungsi trigonometri sudut kuadran ini penting untuk dianalisis lebih lanjut. Hal ini dikarenakan hasil analisis kesalahan mahasiswa dapat digunakan untuk memperbaiki pemahaman mahasiswa dan juga digunakan untuk memperbaiki pembelajaran yang dilakukan oleh guru atau dosen di kelas (Setiawan, 2020b, 2020c, 2020a). Selain itu kesalahan mahasiswa juga dapat digunakan untuk mengungkapkan kesalahpahaman mahasiswa serta memperbaikinya (Ball, 1993; Ball \& Friel, 1991; Borasi, 1994; Webb \& Mastergeorge, 2003). Jadi 
penting untuk melakukan penelitian tentang kesalahan mahasiswa, karena dapat mengungkapkan kesalahpahaman mahasiswa dan memperbaiki kesalahpahaman tersebut.

Pentingnya penelitian tentang analisis kesalahan-kesalahan mahasiswa dalam materi trigonometri menyebabkan beberapa peneliti tertarik untuk melakukan penelitian. Penelitian Jaelani (2017) menganalisis kesalahan mahasiswa semester pertama program studi pendidikan matematika yang menunjukkan bahwa kesalahan mahasiswa semester pertama yaitu tidak memperhatikan kuadran, salah dalam menggunakan rumus trigonometri dan salah dalam menggambar grafik fungsi trigonometri. Penelitian Imelda (2018) juga menunjukkan bahwa mahasiswa kesulitan dalam menggunakan rumus-rumus trigonometri dalam menyelesaikan masalah trigonometri. Penelitian Nabie et al (2018) menunjukkan bahwa mahasiswa calon guru menganggap trigonometri itu sulit, abstrak, dan membosankan untuk dipelajari. Penelitian lain juga menunjukkan kesalahan dalam menentukan sudut istimewa (Setiawan, 2021). Akan tetapi penelitian-penelitian yang telah dilakukan sebelumnya tidak membahas materi nilai fungsi trigonometri sudut kuadran. Oleh karena itu masih dibutuhkan penelitian untuk menganalisis kesalahan mahasiswa dalam menentukan nilai sudut kuadran.

Berbeda dengan penelitian sebelumnya (Imelda, 2018; Jaelani, 2017; Nabie et al., 2018; Setiawan, 2021), penelitian ini fokus pada analisis kesalahan-kesalahan mahasiswa semester pertama dalam menentukan nilai fungsi trigonometri sudut kuadran. Tujuan penelitian ini adalah mendeskripsikan kesalahan-kesalahan mahasiswa semester pertama program studi pendidikan matematika dalam menentukan nilai fungsi trigonometri sudut kuadran beserta faktor-faktor penyebabnya. Hasil penelitian ini dapat digunakan oleh siswa maupun mahasiswa untuk memperbaiki kesalahan mereka dalam menentukan nilai fungsi trigonometri sudut kuadran. Selain itu hasil penelitian ini juga dapat digunakan untuk memperbaiki pembelajaran tentang materi nilai fungsi trigonometri sudut kuadran yang dilakukan guru maupun dosen di kelas. Melalui penelitian ini diharapkan dapat terungkap kesalahan mahasiswa dalam menentukan nilai fungsi trigonometri sudut kuadran.

\section{METODE}

Metode penelitian ini merupakan penelitian deskriptif kualitatif dengan tujuan untuk mendeskripsikan kesalahan-kesalahan mahasiswa semester pertama dalam menentukan nilai fungsi trigonometri sudut kuadran. Pendekatan penelitian ini merupakan pendekatan studi kasus terhadap 6 subjek penelitian, yaitu mahasiswa program studi pendidikan matematika yang mengalami kesalahan dalam menentukan nilai fungsi trigonometri sudut kuadran. Proses pemilihan subjek dilakukan dalam tiga langkah. Langkah pertama adalah meminta 82 mahasiswa program studi pendidikan matematika di salah satu Perguruan Tinggi di Kota Malang untuk menyelesaikan soal Ujian Tengah Semester (UTS) yang terdiri dari 5 soal uraian yang salah satunya adalah materi fungsi trigonometri sudut 
kuadran. Langkah kedua adalah mengoreksi jawaban mahasiswa berdasarkan kategori jawaban benar dan salah. Diperoleh 42 mahasiswa berhasil menjawab benar dan 40 mahasiswa menjawab salah dari soal tentang fungsi trigonometri sudut kuadran (lihat Gambar 1). Langkah ketiga adalah menglasifikasikan kesalahan jawaban dari 40 mahasiswa berdasarkan kategori kesalahan prinsip, kesalahan hitung, dan kesalahan fakta (lihat Tabel 1). Dari hasil klasifikasi diperoleh 5 karakteristik kesalahan (lihat Tabel 2). Dari 4 karakteristik kesalahan diambil 1 mahasiswa sebagai subjek penelitian, sedangkan untuk karakteristik kesalahan hitung diambil 2 subjek (karena mahasiswa yang mengalami kesalahan hitung cukup banyak). Jadi diperoleh total subjek penelitian ini adalah 6 subjek penelitian.

Sesuai dengan jenis penelitian ini (yaitu penelitian deskriptif kualitatif), maka data yang dikumpulkan dalam penelitian ini terdiri dari hasil pekerjaan subjek dan transkrip hasil wawancara. Cara pengumpulan data hasil pekerjaan subjek dilakukan dengan mengumpulkan hasil pekerjaan 6 subjek penelitian ini. Sedangkan cara pengumpulan data transkrip hasil wawancara dilakukan dengan melakukan wawancara secara terbuka dengan subjek penelitian dengan tujuan untuk mengetahui faktor-faktor penyebab kesalahan. Wawancara dilakukan melalui whatsapp yang hasil wawancara direkam dan kemudian ditranskrip, sehingga diperoleh data yang berupa transkrip hasil wawancara dengan subjek.

Sesuai dengan data yang dikumpulkan dalam penelitian ini, maka instrumen yang disusun terdiri dari 3 soal fungsi trigonometri sudut kuadran yang dapat dilihat dalam Gambar 1. Dari Gambar 1 dapat dilihat bahwa soal pertama memuat sudut kuadran positif, soal kedua memuat sudut kuadran negatif, dan soal ketiga melibatkan nilai fungsi trigonometri yang tidak terdefinisi. Ketiga soal ini dapat digunakan untuk mengetahui kesalahan mahasiswa dalam menentukan nilai fungsi trigonometri sudut kuadran. Misalnya untuk soal pertama terdapat nilai dari $\cot 90^{\circ}$, jika mahasiswa mengubah ke dalam bentuk $\cot 90^{\circ}=\frac{1}{\tan 90^{\circ}}$, maka mahasiswa akan terjebak ke dalam hasil $\cot 90^{\circ}=\frac{1}{\infty}$ yang berakibat mahasiswa salah dalam menentukan nilai dari $\cot 90^{\circ}$. Misalnya untuk soal kedua adalah $\cos ^{2}\left(-90^{0}\right)$, jika mahasiswa tidak dapat memahami maksud bentuk $\cos ^{2}\left(-90^{\circ}\right)$, maka mahasiswa akan terjebak ke dalam kesalahan memahaminya, sehingga mahasiswa akan menulis $\cos ^{2}\left(-90^{0}\right)=$ $-\cos ^{2}\left(90^{\circ}\right)$. Sedangkan untuk soal ketiga dapat mengidentifikasi kesalahan hitung yang dilakukan oleh mahasiswa, yaitu bentuk $\sec ^{2} 270^{0}=$ tidak terdefinisi. Jika mahasiswa tidak berhati-hati dalam menjumlahkan suatu bilangan dengan bentuk yang tidak terdefinisi, maka mahasiswa akan salah dalam melakukan perhitungan. Jadi secara umum dapat dikatakan bahwa ketiga instrumen ini valid untuk digunakan dalam mengidentifikasi kesalahan-kesalahan mahasiswa dalam menentukan nilai fungsi trigonometri sudut kuadran. 
Tentukan nilai dari fungsi trigonometri berikut.

(a) $2 \sec 0^{0}+4 \cot ^{2} 90^{\circ}+\cos 360^{\circ}+\sec ^{2} 180^{\circ}-3 \sin ^{2} 360=\cdots$

(b) $\sin ^{2}\left(-90^{\circ}\right)+\cos ^{2}\left(-90^{\circ}\right)+\cos ^{2}\left(-180^{\circ}\right)+\sin ^{2}\left(-180^{\circ}\right)=\cdots$

(c) $2 \sec 0^{\circ}+5 \sin ^{2} 90^{\circ}+\cos 180^{\circ}+\sec ^{2} 270^{\circ}-3 \tan ^{2} 360=\cdots$

Gambar 1. Instrumen Penelitian

Analisis hasil pekerjaan subjek dilakukan dengan menglasifikasikan kesalahan hasil pekerjaan berdasarkan kesalahan prinsip, kesalahan hitung, dan kesalahan fakta (lihat Tabel 1). Pemilihan kesalahan prinsip, kesalahan hitung, dan kesalahan fakta didasarkan pada materi dan instrumen yang digunakan dalam penelitian. Materi tentang nilai fungsi trigonometri sudut kuadran lebih menekankan pada penerapan perbandingan trigonometri segitiga. Jika mahasiswa salah dalam menerapkan perbandingan trigonometri segitiga, maka mahasiswa akan terjebak dalam kesalahan prinsip. Seperti yang disampaikan oleh beberapa peneliti, bahwa kesalahan prinsip adalah kesalahan dalam menerapkan sifat-sifat atau aturan dalam menyelesaikan masalah (Muthukrishnan, Kee, \& Sidhu, 2019; Oktaviani, 2017; Setiawan, 2020c). Sedangkan soal dalam penelitian ini melibatkan operasi hitung. Jika mahasiswa salah dalam melakukan operasi hitung, maka mahasiswa akan mengalami kesalahan hitung. Selanjutnya, jika mahasiswa salah dalam mengidentifikasi informasi yang ada dalam soal, maka mahasiswa akan terjebak ke dalam kesalahan fakta. Seperti yang disampaikan oleh beberapa peneliti yang mengatakan bahwa kesalahan fakta adalah kesalahan dalam memahami informasi yang ada dalam soal atau kesalahan dalam memahami simbol-simbol dalam matematika (Muthukrishnan et al., 2019; Oktaviani, 2017; Setiawan, 2020c). Jadi dapat dikatakan bahwa analisis kesalahan mahasiswa dalam menentukan nilai fungsi trigonometri sudut kuadran berdasarkan kesalahan prinsip, kesalahan hitung, dan kesalahan fakta telah sesuai dengan materi nilai fungsi trigonometri sudut kuadran dan instrumen penelitian.

Selanjutnya, analisis transkrip hasil wawancara dilakukan dengan analisis pengkodean, yaitu mengodekan kata-kata yang ada dalam transkrip hasil wawancara dengan tujuan untuk mengetahui faktor-faktor penyebab kesalahan mahasiswa dalam menentukan nilai fungsi trigonometri sudut kuadran. Karena melalui wawancara mendalam ini, maka kesalahpahaman mahasiswa dapat teridentifikasi (Kalyuga, 2009).

Tabel 1. Kerangka Kerja Klasifikasi Kesalahan Mahasiswa

\begin{tabular}{|l|l|}
\hline \multicolumn{1}{|c|}{ Jenis Kesalahan } & \multicolumn{1}{c|}{ Indikator-Indikator Kesalahan } \\
\hline Kesalahan Prinsip & $\begin{array}{l}\text { Kesalahan dalam menerapkan cara-cara, sifat-sifat, atau aturan dalam } \\
\text { menentukan nilai fungsi trigonometri sudut kuadran. }\end{array}$ \\
\hline Kesalahan Hitung & Kesalahan dalam menentukan hasil operasi hitung. \\
\hline Kesalahan Fakta & $\begin{array}{l}\text { Kesalahan dalam mengidentifikasi informasi yang ada dalam soal. } \\
\text { Kesalahan dalam memahami notasi matematika. }\end{array}$ \\
\hline
\end{tabular}




\section{HASIL DAN DISKUSI}

Hasil penelitian menunjukkan bahwa terdapat 40 mahasiswa program studi pendidikan matematika semester pertama yang mengalami kesalahan dalam menentukan nilai fungsi trigonometri sudut kuadran. Selanjutnya, hasil pekerjaan dari 40 mahasiswa tersebut diklasifikasikan berdasarkan jenis kesalahan, sehingga diperoleh hasil klasifikasi kesalahan mahasiswa dalam menentukan nilai fungsi trigonometri sudut kuadran yang dapat dilihat dalam Tabel 2.

Tabel 2. Hasil Klasifikasi Kesalahan Menentukan Nilai Fungsi Trigonometri Sudut Kuadran

\begin{tabular}{|c|c|c|c|}
\hline $\begin{array}{c}\text { Jenis } \\
\text { Kesalahan }\end{array}$ & $\begin{array}{l}\text { Indikator-Indikator } \\
\text { Kesalahan }\end{array}$ & $\begin{array}{c}\text { Kesalahan Menentukan Nilai Fungsi } \\
\text { Trigonometri Sudut Kuadran }\end{array}$ & $\begin{array}{c}\text { Banyak } \\
\text { Mahasiswa }\end{array}$ \\
\hline \multirow[t]{3}{*}{$\begin{array}{l}\text { Kesalahan } \\
\text { Prinsip }\end{array}$} & \multirow{3}{*}{$\begin{array}{l}\text { Kesalahan dalam } \\
\text { menerapkan cara- } \\
\text { cara, sifat-sifat dalam } \\
\text { menentukan nilai } \\
\text { fungsi trigonometri } \\
\text { sudut kuadran. }\end{array}$} & $\begin{array}{l}\text { Kesalahan menerapkan identitas kebalikan } \\
\left.\text { (misalnya } \cot \theta=\frac{1}{\tan \theta}\right)\end{array}$ & 2 \\
\hline & & $\begin{array}{l}\text { Kesalahan dalam menerapkan perbandingan } \\
\text { trigonometri. }\end{array}$ & 2 \\
\hline & & $\begin{array}{l}\text { Kesalahan mengubah fungsi trigonometri } \\
\text { sudut kuadran negatif ke sudut kuadran } \\
\text { positif yang melibatkan bentuk kuadrat. }\end{array}$ & 1 \\
\hline $\begin{array}{l}\text { Kesalahan } \\
\text { Hitung }\end{array}$ & $\begin{array}{l}\text { Kesalahan dalam } \\
\text { menentukan hasil } \\
\text { operasi hitung }\end{array}$ & $\begin{array}{l}\text { Kesalahan dalam menentukan hasil } \\
\text { penjumlahan antara bilangan real dengan } \\
\text { bentuk yang tidak terdefinisi. }\end{array}$ & 33 \\
\hline $\begin{array}{l}\text { Kesalahan } \\
\text { Fakta }\end{array}$ & $\begin{array}{l}\text { Kesalahan dalam } \\
\text { mengidentifikasi } \\
\text { informasi yang ada } \\
\text { dalam soal. }\end{array}$ & Kesalahan dalam menuliskan soal. & 2 \\
\hline & & Total & 40 \\
\hline
\end{tabular}

Dari hasil klasifikasi kesalahan mahasiswa dalam menentukan nilai fungsi trigonometri sudut kuadran akan diambil satu subjek dari masing-masing kesalahan mahasiswa (kecuali untuk kesalahan hitung akan diambil 2 subjek). Diperoleh 6 subjek penelitian ini yang selanjutnya akan dianalisis hasil pekerjaan untuk mendeskripsikan kesalahan yang dilakukan mahasiswa. Dari keenam subjek tersebut juga akan dilakukan wawancara untuk mengetahui faktor-faktor penyebab kesalahan mahasiswa. Hasil analisis dari pekerjaan dan transkrip wawancara dengan subjek dipaparkan berikut ini.

\section{Kesalahan Prinsip}

Kesalahan prinsip yang pertama adalah kesalahan dalam menerapkan identitas kebalikan untuk menentukan nilai fungsi trigonometri sudut kuadran. Misalnya nilai dari $\cot 90^{\circ}=\frac{x}{y}=\frac{0}{1}=0$, tetapi jika kita menggunakan identitas kebalikan maka diperoleh hasil yang salah dari $\cot 90^{\circ}=$ $\frac{1}{\tan 90^{\circ}}=\frac{1}{\text { tdkterdefinisi. }}$. Ini artinya penggunaan identitas kebalikan harus lebih teliti saat digunakan untuk menentukan nilai fungsi trigonometri sudut kuadran. Terdapat 2 mahasiswa yang mengalami kesalahan ini. Dari 2 mahasiswa tersebut diambil 1 mahasiswa yang dapat memberikan penjelasan 
tentang hasil pekerjaannya sebagai subjek pertama (S1) penelitian ini. Hasil pekerjaan dari subjek pertama (S1) dapat dilihat dalam Gambar 2.

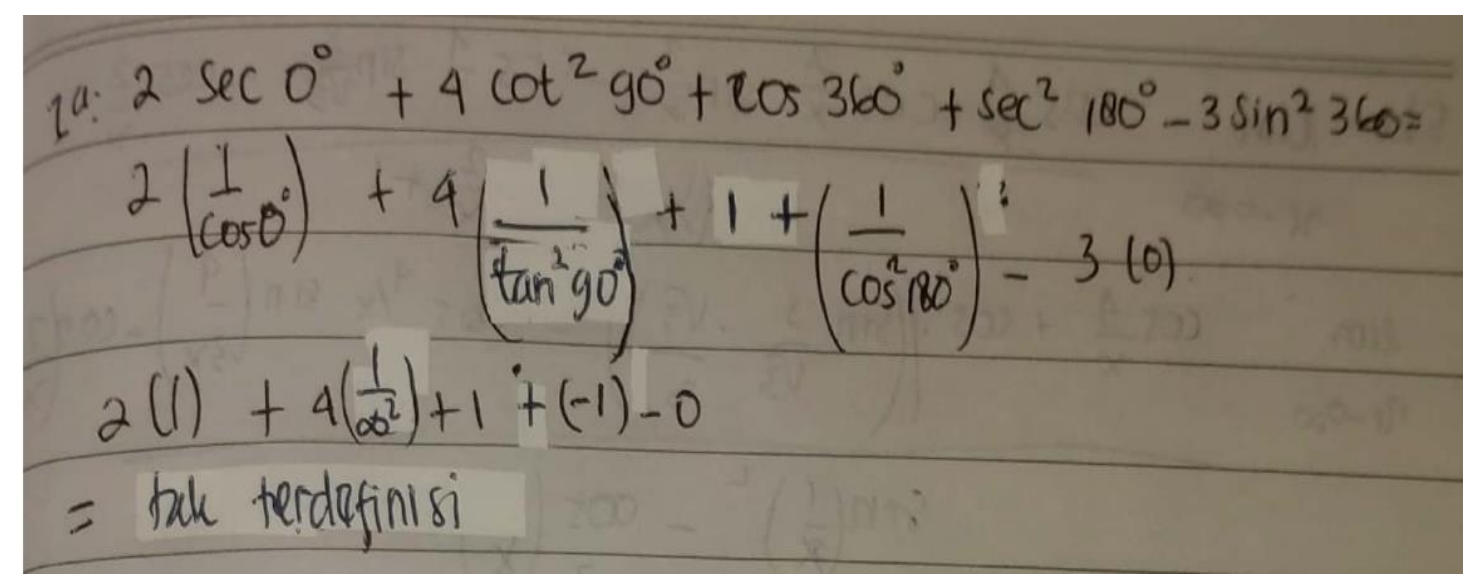

Gambar 2. Kesalahan Prinsip Berupa Penerapan Identitas Kebalikan

Dari Gambar 2 dapat dilihat bahwa subjek menentukan nilai sec $0^{\circ}, \cot 90^{\circ}$, dan $\sec 180^{\circ}$ dengan menggunakan identitas kebalikan, yaitu sec $0^{0}=\frac{1}{\cos 0^{0}}, \cot ^{2} 90^{\circ}=\frac{1}{\tan ^{2} 90^{0}}$, dan $\sec ^{2} 180^{\circ}=$ $\frac{1}{\cos ^{2} 180^{\circ}}$. Akibatnya subjek salah dalam menentukan hasil $\cot ^{2} 90^{\circ}$ dan benar dalam menentukan hasil $\sec 0^{0}$ dan $\sec ^{2} 180^{\circ}$. Faktor-faktor penyebab kesalahan ini dapat diketahui dari cuplikan hasil wawancara berikut.

$P \quad: \quad$ Mengapa Anda menuliskan hasil dari $\cot ^{2} 90^{0}=\frac{1}{\tan ^{2} 90^{0}}=$ tidak terdefinisi?

S1 : Karena bentuk secan, cosecan, dan cotangen dapat diubah ke dalam bentuk identitats kebalikan pak, jadi saya ubah semua ke bentuk identitas kebalikan untuk mempermudah dalam menjawab soal pak.

Dari cuplikan transkrip wawancara diperoleh bahwa subjek mengubah bentuk secan, cosecan, dan cotangent ke dalam bentuk identitas kebalikan tanpa menganalisis lebih lanjut mengenai fungsi trigonometri sudut kuadran yang dapat diubah ke dalam bentuk identitas kebalikan dan yang tidak dapat diubah. Misalnya, untuk $\cot 90^{\circ}$ tidak dapat diubah ke dalam bentuk identitas kebalikan, karena akan mendapatkan hasil yang salah (dimana $\cot 90^{\circ}=\frac{0}{1}=0$, sedangkan $\tan 90^{\circ}=\frac{1}{0}=$ tidak terdefinisi). Jadi dapat dikatakan bahwa faktor penyebab kesalahan prinsip yang berupa kesalahan menerapkan identitas kebalikan untuk menentukan nilai fungsi trigonometri sudut kuadran adalah pemikiran intuitif, yaitu hanya berdasarkan persepsi, tanpa menganalisis lebih lanjut mengenai fungsi trigonometri yang dapat diubah ke dalam bentuk identitas kebalikannya. 
Kesalahan prinsip yang kedua adalah kesalahan dalam menerapkan perbandingan trigonometri untuk menentukan nilai fungsi trigonometri sudut kuadran. Misalnya nilai dari $\sin 180^{\circ}=\frac{y}{r}=\frac{0}{1}=0$, tetapi jika salah dalam menerapkan perbandingan trigonpmetri akan berakibat salah dalam menentukan nilai fungsi trigonometri sudut kuadran. Misalnya yang termasuk kesalahan dalam menerapkan perbandingan trigonometri adalah $\sin 180^{\circ}=\frac{x}{r}=\frac{-1}{1}=-1$. Terdapat 2 mahasiswa yang mengalami kesalahan ini. 1 mahasiswa setelah dikonfirmasi tidak memberikan penjelasan, sedangkan mahasiswa lainnya memberikan penjelasannya. Satu mahasiswa yang memberikan penjelasannya ini selanjutnya dijadikan sebagai subjek kedua (S2) penelitian ini. Hasil pekerjaan subjek kedua dapat dilihat dalam Gambar 3.

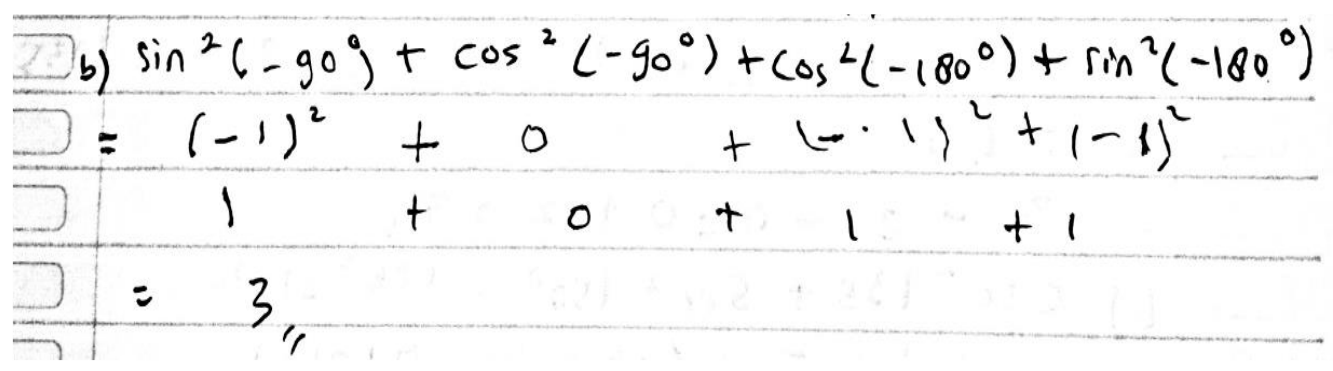

Gambar 3. Kesalahan Menentukan Nilai $\sin ^{2}\left(-180^{\circ}\right)$

Dari Gambar 3 dapat dilihat bahwa subjek menuliskan hasil yang salah dari $\sin ^{2}\left(-180^{\circ}\right)=$ $(-1)^{2}=1$, dimana hasil yang benar adalah $\sin ^{2}\left(-180^{\circ}\right)=(0)^{2}=0$. Penyebab kesalahan subjek ini dapat diketahui dari cuplikan wawancara berikut.

$P \quad: \quad$ Mengapa Anda menuliskan hasil dari $\sin ^{2}\left(-180^{\circ}\right)=(-1)^{2}=1$ ?

S2 : Mohon maaf pak, saya salah itu pada saat itu saya mengira $\sin$ itu $\sin \theta=\frac{x}{r}$, karena nilai $x=-1$ dan $r=1$ untuk sudut $180^{\circ}$, maka saya menuliskannya $\sin ^{2}\left(-180^{\circ}\right)=\left(\frac{-1}{1}\right)^{2}=(-1)^{2}=1$. Saya juga waktu itu terburu-buru pak, sehingga saya tidak mengoreksi lagi pak.

Dari cuplikan transkrip wawancara dapat diketahui bahwa subjek mengira perbandingan trigonometri untuk $\sin$ adalah $\sin \theta=\frac{\mathrm{x}}{\mathrm{r}}$, sehingga subjek salah dalam menentukan nilai dari $\sin ^{2}\left(-180^{\circ}\right)$. Perkiraan yang dilakukan oleh subjek dikarenakan terburu-buru dan tidak mengoreksi jawaban yang diperoleh. Jadi penyebab kesalahan dalam menentukan perbandingan adalah pemikiran intuitif yang hanya memperkirakan perbandingan trigonometri sudut. Oleh karena itu penting untuk menganalisis dan mengoreksi kembali jawaban yang diperoleh dalam menentukan nilai fungsi trigonometri sudut kuadran. 
Kesalahan prinsip yang ketiga adalah kesalahan dalam mengubah fungsi trigonometri sudut kuadran negatif ke sudut kuadran positif yang melibatkan bentuk fungsi trigonometri kuadrat. Misalnya $\cos ^{2}\left(-180^{\circ}\right)$ ditulis menjadi $-\cos ^{2}\left(180^{\circ}\right)$, sehingga mahasiswa menjawab $\cos ^{2}\left(-180^{\circ}\right)=-\cos ^{2}\left(180^{\circ}\right)=-(-1)^{2}=-1$ yang berakibat salah dalam menentukan nilai dari $\cos ^{2}\left(-180^{\circ}\right)$. Seharusnya yang diperhatikan adalah menulis $\cos ^{2}\left(-180^{\circ}\right)=\left(\cos \left(-180^{\circ}\right)\right)^{2}=$ $\left(-\cos 180^{\circ}\right)^{2}=\left(\cos 180^{\circ}\right)^{2}=(-1)^{2}=1$. Terdapat satu mahasiswa yang mengalami kesalahan ini, yang selanjutnya dipilih sebagai subjek ketiga (S3) dalam penelitian ini. Hasil pekerjaan subjek ketiga ini dapat dilihat dalam Gambar 4.

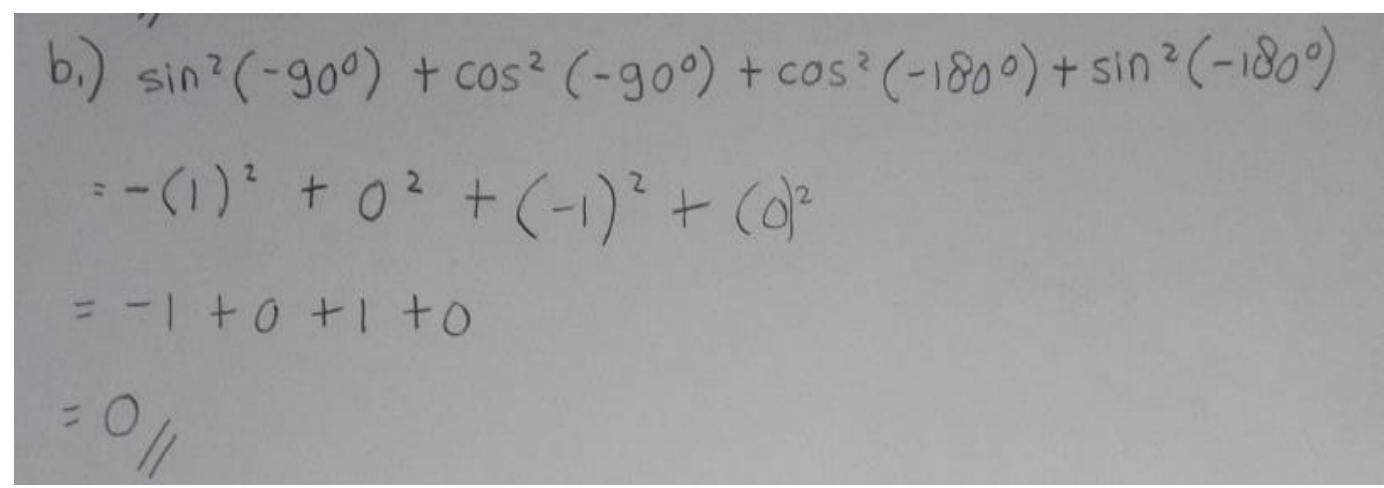

Gambar 4. Kesalahan Menuliskan Hasil Dari $\sin ^{2}\left(-90^{0}\right)$

Dari Gambar 4 dapat dilihat bahwa subjek mengalami kesalahan dalam menuliskan hasil dari $\sin ^{2}\left(-90^{\circ}\right)$. Kesalahan ini dikarenakan subjek mengubah terlebih dahulu dari sudut kuadran negatif ke dalam bentuk sudut kuadran positif tanpa memperhatikan bentuk kuadrat. Subjek mengubah $\sin ^{2}\left(-90^{\circ}\right)$ menjadi $-\sin ^{2}\left(90^{\circ}\right)$, sehingga subjek menjawab $\sin ^{2}\left(-90^{\circ}\right)=-\sin ^{2}\left(90^{0}\right)=$ $-(1)^{2}=-1$. Penyebab kesalahan subjek ini dapat diketahui dari cuplikan wawancara berikut ini.

$P \quad: \quad$ Mengapa Anda menulis $\sin ^{2}\left(-90^{0}\right)=-(1)^{2}=-1$ ?

S6 : Dulu waktu di SMA saya diajari tentang $\sin \left(-90^{\circ}\right)$ dan $\sin \left(-180^{\circ}\right)$ menjadi $-\sin \left(90^{\circ}\right)$ dan $-\sin \left(180^{\circ}\right)$, sedangkan kalau $\cos \left(-90^{\circ}\right)$ dan $\cos \left(-180^{\circ}\right)$ menjadi $\cos \left(90^{\circ}\right)$ dan $\cos \left(180^{\circ}\right)$. Jadi kalau $\sin ^{2}\left(-90^{\circ}\right)$ menjadi $-\sin ^{2}\left(90^{\circ}\right)$ sama dengan negatif satu dikuadratkan $\left(-(1)^{2}\right)$, negatifnya ditaruh depan pak.

\section{Karena kalau misalkan $\sin ^{2} x$ sama dengan sin dari $x$ kemudian dikuadratkan.}

Jadi terus $\sin \left(-90^{\circ}\right)$ sama dengan $-\sin \left(90^{\circ}\right)$. Jadi $\sin \left(90^{\circ}\right)$ itu kan sama dengan 1 , maka terus dikuadratkan dan ditambah negatif didepannya.

Dari cuplikan wawancara dapat diketahui bahwa subjek memahami jika $\sin \left(-90^{\circ}\right)$ dapat diubah menjadi $-\sin \left(90^{\circ}\right)$, maka subjek juga mengartikan bahwa $\sin ^{2}\left(-90^{\circ}\right)$ dapat diubah menjadi $-\sin ^{2}\left(-90^{\circ}\right)$, sehingga subjek melakukan kesalahan dalam menuliskan hasil dari $\sin ^{2}\left(-90^{\circ}\right)$, yaitu $\sin ^{2}\left(-90^{\circ}\right)=-\sin ^{2}\left(90^{\circ}\right)=-(1)^{2}=-1$. Dari cuplikan transkrip wawancara juga dapat diketahui 
bahwa subjek sudah mengetahui aturan $\sin ^{2} x=(\sin x)^{2}$. Akan tetapi subjek secara langsung menuliskan bahwa $\sin ^{2}\left(-90^{\circ}\right)=-\sin ^{2}\left(90^{\circ}\right)$ tanpa menganalisis lebih lanjut. Ini artinya, penyebab kesalahan subjek menuliskan hasil dari $\sin ^{2}\left(-90^{\circ}\right)=-\sin ^{2}\left(90^{\circ}\right)$ adalah subjek secara langsung mengubah sudut negatif ke dalam sudut positif tanpa memperhatikan aturan kuadrat dari fungsi trigonometri, sehingga subjek salah dalam menjawab soal.

\section{Kesalahan Hitung}

Kesalahan hitung yang dilakukan oleh mahasiswa adalah kesalahan dalam menentukan hasil operasi hitung suatu bilangan dengan bentuk yang tidak terdefinisi. Misalnya kesalahan dalam menentukan hasil operasi hitung adalah $6+\frac{1}{0}=6$, jawaban yang benar seharusnya adalah $6+\frac{1}{0}=$ tidak terdefinisi. Terdapat 33 mahasiswa yang mengalami kesalahan ini. dari 33 mahasiswa dipilih 2 mahasiswa sebagai subjek keempat (S4) dan subjek kelima (S5). Hasil pekerjaan subjek keempat dapat dilihat dalam Gambar 5.

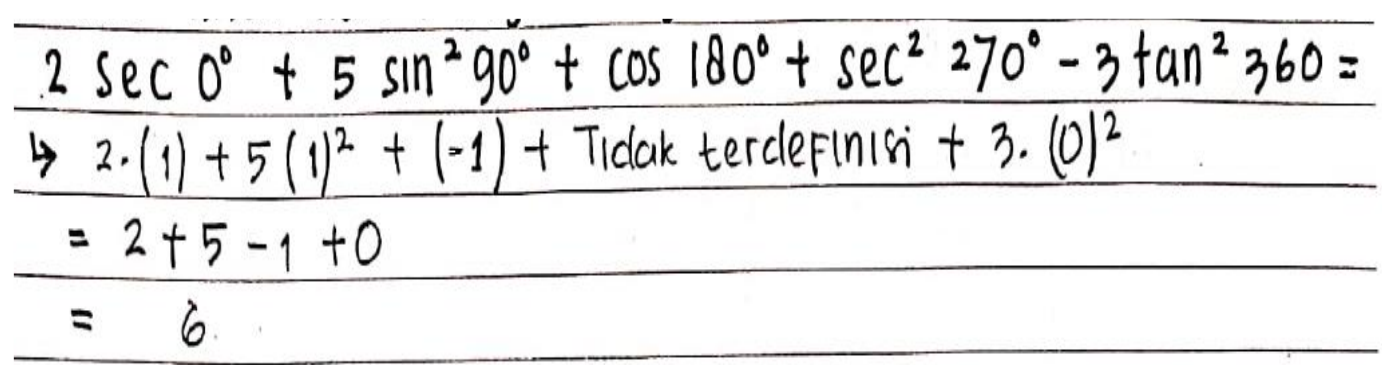

Gambar 5. Kesalahan Menentukan Hasil Operasi Hitung

Dari Gambar 5 dapat dilihat bahwa subjek menentukan hasil operasi $2(1)+5(1)^{2}+(-1)+$ tidak terdefinisi $+3(0)^{2}=2+5-1+0=6$ dengan menghilangkan tidak terdefinisi. Alasan subjek menggunakan cara tersebut dapat diketahui dari cuplikan wawancara berikut.

$P \quad:$ Coba jelaskan cara yang Anda gunakan?

S4 : Saya melihat tabel untuk menentukan nilai fungsi trigonometri tersebut, ... dimana nilai dari $\sec ^{2} 270^{0}$ adalah tidak terdefinisi. ... nah dalam soal ini menurut saya untuk yang tidak terdefinisi itu tidak dicantumkan untuk mengitung, jadi diabaikan saja.

$P \quad$ : Mengapa untuk yang tidak terdefinisi diabaikan?

S4 : Karena menurut saya tidak mempunyai spesifik angka, sehingga diabaikan atau tidak dicantumkan.

Dari cuplikan transkrip wawancara dapat diketahui bahwa subjek dapat menentukan dengan benar nilai dari $\sec ^{2} 270^{\circ}$, yaitu tidak terdefinisi. Kemudian subjek menghilangkan tidak terdefinisi dikarenakan menurut subjek tidak memiliki spesifikasi angka, sehingga subjek hanya menentukan 
hasil operasi hitung yang tidak melibatkan bentuk tidak terdefinisi. Ini artinya penyebab kesalahan subjek melakukan kesalahan perhitungan adalah menghilangkan nilai fungsi trigonometri yang tidak terdefinisi, karena dianggap tidak mempunyai spesifikasi nilai atau bilangan.

Selanjutnya hasil pekerjaan subjek kelima (S5) yang juga melakukan kesalahan hitung dalam menentukan hasil operasi hitung dapat dilihat dalam Gambar 6.

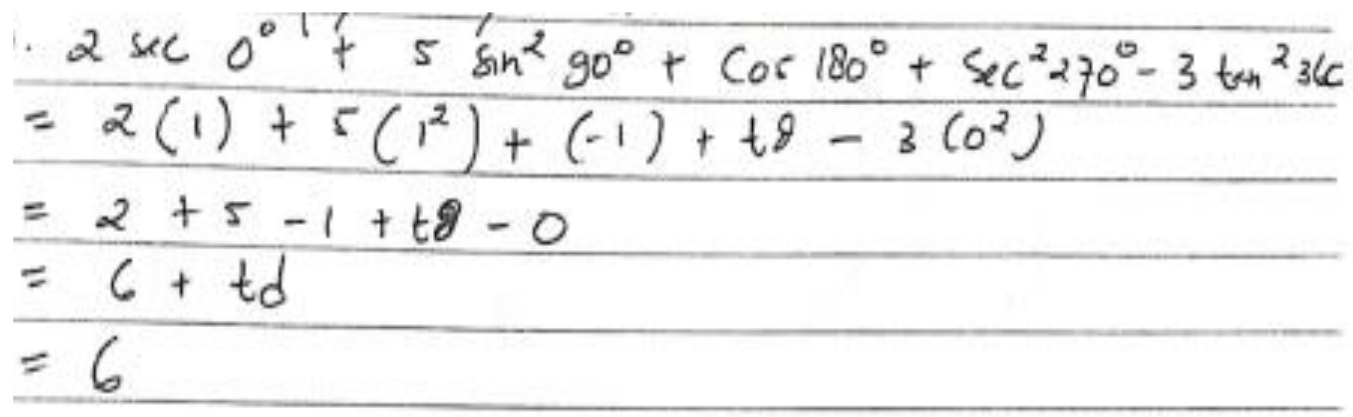

Gambar 6. Kesalahan Menentukan Hasil Operasi Hitung

Dari Gambar 6 dapat dilihat bahwa subjek melakukan kesalahan dengan menentukan hasil dari 6 ditambah tidak terdefinisi adalah 6. Alasan subjek menjawab seperti ini dapat dilihat dalam cuplikan transkrip hasil wawancara berikut.

$P \quad: \quad$ Mengapa hasil dari $6+$ tidak terdefinisi hasilnya $6 ?$

S5 : Hasil dari $6+$ tidak terdefinisi hasilnya tetap 6. Karena operasi penjumlahan, maka tidak terdefinisi tidak berpengaruh, jadi hasilnya tetap 6.

Dari cuplikan hasil wawancara dapat diketahui bahwa subjek mengatakan tidak terdefinisi tidak berpengaruh terhadap penjumlahan, sehingga subjek menuliskan hasil dari $6+$ tidak terdefinisi $=$ 6. Ini artinya penyebab kesalahan operasi hitung dalam hal ini adalah menghilangkan tidak terdefinisi, karena dianggap tidak memiliki pengaruh.

\section{Kesalahan Fakta}

Kesalahan fakta yang dilakukan oleh mahasiswa adalah kesalahan dalam mengidentifikasi informasi yang diketahui dalam soal. Terdapat 2 mahasiswa yang mengalami kesalahan fakta ini. Selanjutnya, dari 2 mahasiswa tersebut dipilih satu mahasiswa yang dapat memberikan penjelasan dari jawabannya sebagai subjek keenam (S6) dalam penelitian ini. Hasil pekerjaan subjek keenam dapat dilihat dalam Gambar 7. 


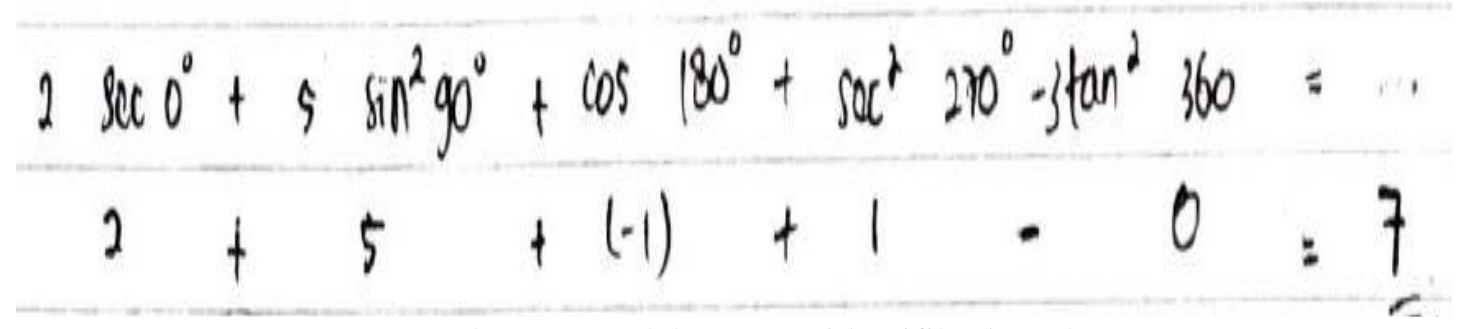

Gambar 7. Kesalahan Mengidentifikasi Soal

Dari Gambar 7 dapat dilihat bahwa kesalahan subjek yaitu menentukan hasil dari $\sec ^{2} 270^{0}$ adalah 1. Jawaban yang benar dari $\sec ^{2} 270^{\circ}=$ tidak terdefinisi, sehingga subjek mengalami kesalahan dalam menentukan nilai fungsi trigonometri sudut kuadran. Hal yang menyebabkan subjek melakukan kesalahan dalam mengidentifikasi informasi dapat diketahui dari cuplikan wawancara berikut.

$P \quad: \quad$ Mengapa Anda menuliskan hasil dari $\sec ^{2} 270^{0}=1$ ?

S6 : Saya salah pak, saya kira itu $\mathbf{c s c}^{2} \mathbf{2 7 0}^{\mathbf{0}}$, sehingga saya menulis 1.

Dari cuplikan transkrip wawancara diperoleh bahwa subjek mengira $\sec ^{2} 270^{0}$ adalah $\csc ^{2} 270^{0}$, sehingga subjek salah dalam menjawab soal. Ini artinya subjek mengalami kesalahan dalam mengidentifikasi informasi yang ada dalam soal. Penyebab kesalahan ini adalah subjek kurang teliti dalam memperhatikan informasi yang diketahui dalam soal.

Dari hasil analisis pekerjaan dan wawancara di atas, diperoleh deskripsi kesalahan mahasiswa dan faktor penyebabnya dalam menentukan nilai fungsi trigonometri sudut kuadran yang dapat dilihat dalam Tabel 3.

Tabel 3. Deskripsi Kesalahan Menentukan Nilai Fungsi Trigonometri Sudut Kuadran

\begin{tabular}{|c|c|c|}
\hline Jenis Kesalahan & Deskripsi & Faktor-Faktor Penyebabnya \\
\hline Kesalahan Prinsip & $\begin{array}{l}\text { Kesalahan prinsip dalam } \\
\text { menentukan nilai fungsi } \\
\text { trigonometri sudut kuadran terdiri } \\
\text { dari: (1) kesalahan menerapkan } \\
\text { identitas kebalikan, (2) kesalahan } \\
\text { menerapkan perbandingan } \\
\text { trigonometri segitiga; dan (3) } \\
\text { kesalahan dalam mengubah fungsi } \\
\text { trigonometri sudut kuadran negatif } \\
\text { menjadi sudut kuadran positif yang } \\
\text { melibatkan bentuk kuadrat. }\end{array}$ & $\begin{array}{l}\text { Faktor-faktor penyebab dari masing- } \\
\text { masing kesalahan prinsip antara lain: } \\
\text { (1) hanya berdasarkan pada pemikiran } \\
\text { intuitif, yaitu tidak menganalisis lebih } \\
\text { lanjut mengenai fungsi trigonometri } \\
\text { yang tidak dapat diubah ke dalam } \\
\text { identitas kebalikannya saat } \\
\text { menentukan nilai fungsi trigonometri } \\
\text { dari sudut kuadran tertentu; (2) hanya } \\
\text { memperkirakan pendandingan } \\
\text { trigonometri yang dikarenakan } \\
\text { terburu-buru dan tidak mengoreksi } \\
\text { jawaban; (3) secara langsung } \\
\text { mengubah sudut negatif ke dalam } \\
\text { sudut positif tanpa memperhatikan } \\
\text { aturan kuadrat dari fungsi } \\
\text { trigonometri. }\end{array}$ \\
\hline
\end{tabular}




\begin{tabular}{|c|c|c|}
\hline Jenis Kesalahan & $\begin{array}{c}\text { Deskripsi } \\
\end{array}$ & Faktor-Faktor Penyebabnya \\
\hline Kesalahan Hitung & $\begin{array}{l}\text { Kesalahan hitung dalam } \\
\text { menentukan nilai fungsi } \\
\text { trigonometri sudut kuadran adalah } \\
\text { kesalahan dalam menentukan hasil } \\
\text { operasi hitung suatu bilangan real } \\
\text { dengan bentuk tidak terdefinisi. }\end{array}$ & $\begin{array}{l}\text { Faktor yang menyebabkan kesalahan } \\
\text { hitung adalah menghilangkan bentuk } \\
\text { tidak terdefinisi, karena dianggap tidak } \\
\text { mempunyai spesifikasi bilangan atau } \\
\text { dianggap tidak berpengaruh terhadap } \\
\text { operasi hitung. }\end{array}$ \\
\hline Kesalahan Fakta & $\begin{array}{l}\text { Kesalahan fakta dalam menentukan } \\
\text { nilai fungsi trigonometri sudut } \\
\text { kuadran adalah kesalahan dalam } \\
\text { mengidentifikasi informasi yang } \\
\text { ada dalam soal. }\end{array}$ & $\begin{array}{l}\text { Faktor yang menyebabkan kesalahan } \\
\text { fakta adalah kurang teliti dalam } \\
\text { memperhatikan informasi yang ada } \\
\text { dalam soal. }\end{array}$ \\
\hline
\end{tabular}

Hasil penelitian ini berkonstribusi pada pengembangan teori kesalahan pada materi nilai fungsi trigonometri sudut kuadran. Hasil penelitian menunjukkan bahwa kesalahan yang dilakukan oleh mahasiswa dalam menentukan nilai fungsi trigonometri sudut kuadran terdiri dari kesalahan prinsip, kesalahan hitung, dan kesalahan fakta. Hasil penelitian ini sesuai dengan hasil penelitian sebelumnya yang menunjukkan bahwa mahasiswa semester pertama lebih banyak mengalami kesalahan prinsip (Abidin, 2012) dan juga mengalami kesalahan hitung serta kesalahan fakta dalam menyelesaikan masalah trigonometri (Imelda, 2018; Jaelani, 2017; Nabie et al., 2018). Akan tetapi hasil penelitian ini memperluas hasil penelitian sebelumnya dengan menjelaskan kesalahan prinsip, kesalahan hitung, dan kesalahan fakta dalam menentukan nilai fungsi trigonometri sudut kuadran.

Kesalahan pertama adalah kesalahan prinsip dalam menentukan nilai fungsi trigonometri sudut kuadran yang terdiri dari kesalahan menerapkan identitas kebalikan yang tidak sesuai, kesalahan menerapkan perbandingan trigonometri, dan kesalahan dalam mengubah sudut negatif ke dalam sudut positif yang melibatkan bentuk kuadrat dari fungsi trigonometri. Hasil penelitian ini sesuai dengan hasil penelitian sebelumnya yang menunjukkan bahwa mahasiswa semester pertama banyak mengalami kesalahan prinsip dalam menyelesaikan masalah trigonometri (Abidin, 2012) dan mengaplikasikan rumus yang tidak tepat (Jaelani, 2017). Penyebab utama dari kesalahan prinsip ini adalah pemikiran intuitif, yaitu mahasiswa hanya berdasarkan persepsi saja. Hasil ini sesuai dengan hasil penelitian sebelumnya yang menunjukkan bahwa mata kuliah trigonometri lebih banyak melibatkan analisis (Nabie et al., 2018). Hasil penelitian ini memperluas hasil penelitian sebelumnya dengan menunjukkan bahwa pemikiran intuitif tentang penggunaan identitas kebalikan, penerapan perbandingan trigonometri, dan perubahan dari sudut negatif ke dalam sudut positif akan menyebabkan kesalahan prinsip dalam menentukan nilai fungsi trigonometri sudut kuadran. Oleh karena itu, mahasiswa harus melakukan analisis terhadap cara-cara yang mereka gunakan dalam menyelesaikan masalah trigonometri.

Kesalahan kedua adalah kesalahan hitung. Hasil penelitian ini sesuai dengan hasil penelitian sebelumnya yang menunjukkan bahwa mahasiswa semester satu juga mengalami kesalahan hitung dalam menyelesaikan masalah trigonometri (Imelda, 2018). Hasil penelitian ini memperluas hasil penelitian sebelumnya dengan menjelaskan kesalahan hitung pada materi nilai fungsi trigonometri 
sudut kuadran. Nilai fungsi trigonometri sudut kuadran tidak hanya melibatkan nilai tentu (misalnya $\sin 90^{\circ}=1$ ), tetapi juga melibatkan nilai yang tidak terdefinisi (misalnya $\tan 90^{\circ}=$ tidak terdefinisi). Munculnya kesalahan hitung ini disebabkan penjumlahan bilangan real dengan bentuk yang tidak terdefinisi, sehingga bentuk yang tidak terdefinisi dianggap tidak berpengaruh terhadap hasil penjumlahan, yang kemudian dihilangkan oleh mahasiswa. Oleh karena itu perlu dipahami bahwa penjumlahan bilangan real dengan tidak terdefinisi hasilnya adalah tidak terdefinisi. Misalnya $1+3+0,5+$ tidak terdefinisi $=$ tidak terdefinisi.

Kesalahan yang ketiga adalah kesalahan fakta. Hasil penelitian sebelumnya juga menunjukkan bahwa mahasiswa semester pertama mengalami kesalahan fakta dalam menyelesaikan masalah trigonometri (Abidin, 2012; Imelda, 2018). Penyebab kesalahan fakta ini adalah kurang teliti dalam memperhatikan informasi yang ada dalam soal. Ini artinya ketelitian tidak hanya dibutuhkan dalam menjawab soal, tetapi juga dibutuhkan dalam mengidentifikasi informasi yang ada pada soal. Hasil penelitian menunjukkan bahwa kesalahan memahami informasi yang ada dalam soal dapat mengakibatkan kesalahan fakta (Setiawan, 2020c) dan juga mengakibatkan terburu-buru dalam mengambil kesimpulan yang salah (Setiawan, 2020b). Oleh karena itu penting untuk mengidentifikasi informasi yang ada dalam soal secara detail dan menyeluruh agar tidak mengalami kesalahan fakta.

Hasil penelitian ini berimplikasi pada pembelajaran trigonometri untuk mengurangi kesalahan prinsip, kesalahan hitung, dan kesalahan fakta dalam materi nilai fungsi trigonometri sudut kuadran. Implikasi yang pertama adalah pembelajaran untuk mengurangi kesalahan prinsip. Jika dilihat dalam Tabel 3 dapat diketahui bahwa untuk mengurangi kesalahan prinsip dilakukan dengan mengatasi penyebab kesalahan prinsip muncul. Munculnya kesalahan prinsip yang pertama adalah kesalahan dalam menerapkan identitas kebalikan. Mengubah bentuk fungsi trigonometri ke dalam bentuk identitas kebalikan harus dilakukan lebih teliti. Ada beberapa fungsi trigonometri yang melibatkan sudut kuadran tertentu yang tidak dapat diubah ke dalam bentuk identitas kebalikan. Misalnya $\sin 0^{0} \neq \frac{1}{\csc 0^{0}}$, karena $\sin 0^{0}=0$ dan $\csc 0^{0}=$ tidak terdefinisi. Akan tetapi jika identitas ini dibalik, maka akan diperoleh $\csc 0^{0}=\frac{1}{\sin 0^{0}}$, karena $\csc 0^{0}=$ tidak terdefinisi dan $\sin 0^{0}=0$. Jadi secara umum untuk menggunakan identitas kebalikan $\left(a=\frac{1}{b}\right.$, dimana $a$ dan $b$ adalah fungsi trigonometri) dalam menentukan nilai fungsi trigonometri sudut kuadran adalah jika $b \neq$ tidak terdefinisi. Secara detail mengenai nilai fungsi trigonometri untuk sudut kuadran dapat dilihat dalam Tabel 4.

Tabel 4. Nilai Fungsi Trigonometri Sudut Kuadran

\begin{tabular}{|c|c|c|c|c|c|c|}
\hline $\boldsymbol{\theta}$ & $\sin \boldsymbol{\theta}$ & $\cos \boldsymbol{\theta}$ & $\tan \boldsymbol{\theta}$ & $\csc \boldsymbol{\theta}$ & $\sec \boldsymbol{\theta}$ & $\cot \boldsymbol{\theta}$ \\
\hline $0^{0}$ & 0 & 1 & 0 & $\begin{array}{c}\text { Tidak } \\
\text { terdefinisi }\end{array}$ & 1 & $\begin{array}{c}\text { Tidak } \\
\text { terdefinisi }\end{array}$ \\
\hline $90^{0}$ & 1 & 0 & $\begin{array}{c}\text { Tidak } \\
\text { terdefinisi }\end{array}$ & 1 & $\begin{array}{c}\text { Tidak } \\
\text { terdefinisi }\end{array}$ & 0 \\
\hline $180^{0}$ & 0 & -1 & 0 & Tidak & -1 & Tidak \\
\hline
\end{tabular}




\begin{tabular}{|c|c|c|c|c|c|c|}
\hline $270^{0}$ & -1 & 0 & $\begin{array}{c}\text { Tidak } \\
\text { terdefinisi }\end{array}$ & -1 & $\begin{array}{c}\text { Tidak } \\
\text { terdefinisi }\end{array}$ & 0 \\
\hline $360^{0}$ & 0 & 1 & 0 & $\begin{array}{c}\text { Tidak } \\
\text { terdefinisi }\end{array}$ & 1 & $\begin{array}{c}\text { Tidak } \\
\text { terdefinisi }\end{array}$ \\
\hline
\end{tabular}

Munculnya kesalahan prinsip yang kedua adalah karena kesalahan dalam menerapkan perbandingan trigonometri segitiga untuk menentukan nilai fungsi trigonometri sudut kuadran. Kesalahan dalam menerapkan fungsi trigonometri ini dapat diatasi dengan menerapkan akronim SINDEMI (Sin Depan Miring), COSAMI (Cos Samping Miring), dan TANDESA (Tan Depan Samping). Jika akronim ini diterapkan dalam posisi standar (bidang cartesius), maka sisi depan adalah nilai $y$, sisi samping adalah nilai $x$, dan sisi miring adalah nilai $r$. Melalui ketiga akronim ini, maka siswa maupun mahasiswa akan lebih mudah dalam menentukan perbandingan trigonometri segitiga. Hasil penelitian menunjukkan bahwa pembelajaran trigonometri pertama kali yang dikenalkan kepada siswa ataupun mahasiswa adalah dengan akronim SINDEMI, TANDESA, dan COSAMI (Nejad, 2016; Wongapiwatkul \& Laosinchai, 2011).

Munculnya kesalahan prinsip yang ketiga adalah karena mengubah sudut negatif menjadi sudut positif tanpa memperhatikan bentuk kuadrat. Terdapat tiga langkah pembelajaran yang dapat dilakukan. Pertama adalah membelajarkan aturan mengubah sudut negatif menjadi sudut positif. Aturan untuk fungsi sinus adalah $\sin (-\theta)=-\sin \theta$ (misalnya $\sin \left(-90^{\circ}\right)=-\sin 90^{\circ}=-(1)=$ $-1)$. Aturan untuk fungsi cosinus adalah $\cos (-\theta)=\cos \theta\left(\right.$ misalnya $\left.\cos \left(-360^{\circ}\right)=\cos 360^{\circ}=1\right)$. Aturan untuk fungsi tangent adalah $\tan (-\theta)=-\tan \theta$ (misalnya $\tan \left(-180^{\circ}\right)=-\tan 180^{\circ}=$ $-(0)=0)$. Aturan untuk fungsi cosecan adalah $\csc (-\theta)=-\csc \theta$ (misalnya $\csc \left(-90^{\circ}\right)=$ $-\csc 90^{\circ}=-(1)=-1$ ). Aturan untuk fungsi secan adalah $\sec (-\theta)=\sec \theta \quad$ (misalnya $\sec \left(-180^{\circ}\right)=\sec 180^{\circ}=-1$ ). Aturan fungsi cotangent adalah $\cot (-\theta)=-\cot \theta$ (misalnya $\left.\cot \left(-90^{\circ}\right)=-\cot 90^{\circ}=-(0)=0\right)$. Kedua adalah membelajarkan prinsip bentuk kuadrat dari fungsi trigonometri, yaitu $\sin ^{2} \theta=(\sin \theta)^{2}, \cos ^{2} \theta=(\cos \theta)^{2}, \tan ^{2} \theta=(\tan \theta)^{2}, \csc ^{2} \theta=$ $(\csc \theta)^{2}, \sec ^{2} \theta=(\sec \theta)^{2}$, dan $\cot ^{2} \theta=(\cot \theta)^{2}$. Ketiga adalah membelajarkan kaitan aturan perubahan sudut negatif ke sudut positif dengan bentuk kuadrat (misalnya $\sin ^{2}\left(-90^{0}\right)=$ $\left.\left(\sin \left(-90^{\circ}\right)\right)^{2}=\left(-\sin 90^{\circ}\right)^{2}=(-1)^{2}=1\right)$. Dengan ketiga langkah ini, diharapkan kesalahan prinsip dalam mengubah sudut negatif ke dalam sudut positif yang melibatkan bentuk kuadrat dapat diatasi.

Implikasi yang kedua adalah mengurangi kesalahan hitung. Penyebab utama munculnya kesalahan hitung ini adalah kesalahpahaman mahasiswa dalam menjumlahkan bilangan real dengan bentuk tidak terdefinisi. Kesalahpahaman ini dapat diatasi dengan memberikan pemahaman yang benar kepada siswa maupun mahasiswa (Setiawan, 2020a; Setiawan \& Mustangin, 2020a, 2020b). Pemahaman yang benar mengenai hasil penjumlahan bilangan real dengan bentuk yang tidak terdefinisi adalah tidak terdefinisi (misalnya $3+$ tidak terdefinisi $=$ tidak terdefinisi). Dengan 
demikian, jika mahasiswa menyelesaikan masalah mengenai operasi hitung fungsi trigonometri sudut kuadran yang melibatkan nilai fungsi trigonometri yang tidak terdefinisi (misalnya $\csc 0^{0}=$ tidak terdefinisi), maka mahasiswa dapat menjawab dengan benar.

Implikasi yang ketiga adalah mengurangi kesalahan fakta. Penyebab kesalahan fakta ini adalah kurang teliti dalam mengidentifikasi informasi yang ada dalam soal. Ketidaktelitian ini dapat diatasi dengan peran guru atau dosen (Setiawan, 2020e; Setiawan \& Syaifuddin, 2020) dalam membiasakan siswa atau mahasiswa untuk meneliti kembali informasi yang ada dalam soal serta jawaban yang diberikan oleh siswa atau mahasiswa. Hasil penelitian menunjukkan bahwa siswa atau mahasiswa yang meneliti kembali jawaban mereka, cenderung dapat memperbaiki kesalahan mereka (Setiawan, 2020d, 2020f; Setiawan, Purwanto, Parta, \& Sisworo, 2020). Jadi dengan meminta siswa atau mahasiswa untuk meneliti kembali informasi yang ada dalam soal dapat mengatasi kesalahan fakta.

\section{KESIMPULAN}

Kesalahan mahasiswa semester pertama dalam menentukan nilai fungsi trigonometri sudut kuadran terdiri dari kesalahan prinsip, kesalahan hitung, dan kesalahan fakta. Kesalahan prinsip merupakan kesalahan dalam menerapkan identitas kebalikan, kesalahan dalam menerapkan perbandingan trigonometri segitiga, dan kesalahan dalam mengubah sudut negatif ke dalam sudut positif yang melibatkan bentuk kuadrat dari fungsi trigonometri. Penyebab dari kesalahan prinsip ini pada umumnya adalah subjek menggunakan pemikiran intuitif, yaitu hanya didasarkan pada persepsi. Kesalahan hitung yaitu kesalahan dalam menjumlahkan bilangan real dengan bentuk tidak terdefinisi. Penyebab kesalahan hitung ini adalah subjek menganggap bentuk tidak terdefinisi dihilangkan dalam menjumlahkan bilangan real dengan bentuk tidak terdeefinisi. Kesalahan fakta yaitu kesalahan dalam mengidentifikasi informasi yang ada dalam soal yang disebabkan subjek kurang teliti dalam memperhatikan informasi yang ada dalam soal.

Meskipun penelitian ini hanya terbatas dalam materi nilai fungsi trigonometri sudut kuadran, akan tetapi hasil penelitian ini telah berkonstribusi dalam mengembangkan teori kesalahan penyelesaian masalah matematika pada materi nilai fungsi trigonometri sudut kuadran. Oleh karena itu, peneliti merekomendasikan kepada para peneliti untuk menginvestigasi kesalahan-kesalahan pada materi-materi yang ada dalam mata kuliah trigonometri. Hasil penelitian ini akan memberikan manfaat dalam memperbaiki kesalahpahaman mahasiswa dalam mempelajari materi trigonometri serta memberikan manfaat untuk guru atau dosen dalam memperbaiki pembelajaran di kelas.

\section{UCAPAN TERIMA KASIH}

Syukur Alhamdulillah dan terima kasih kepada kedua orang tua yang telah membimbing, memotivasi, dan mendoakan penulis untuk mengejar cita-citanya. Penulis menyampaikan terima kasih kepada Rektor Universitas Islam Malang, yaitu Bapak Prof. Dr. H. Maskuri, M.Si. yang telah 
mendukung pendanaan publikasi karya ilmiah ini melalui Lembaga Penelitian dan Pengabdian Kepada Masyarakat (LPPM) Universitas Islam Malang. Penulis juga menyampaikan terima kasih kepada editor dan reviewer dari Jurnal Cendekia: Jurnal Pendidikan Matematika yang telah mempublikasikan karya ilmiah ini. Penulis menyampaikan terima kasih kepada mahasiswa yang telah meluangkan waktu untuk menjadi subjek dalam penelitian ini.

\section{DAFTAR PUSTAKA}

Abidin, Z. (2012). Analisis Kesalahan Mahasiswa Prodi Pendidikan Matematika Fakultas Tarbiyah IAIN AR-Raniry dalam Mata Kuliah Trigonometri dan Kalkulus 1. Jurnal Ilmiah DIDAKTIKA, 13(1), 183-196.

Ball, D. L. (1993). With an eye on the mathematical horizon: Dilemmas of teaching elementary school mathematics. The Elementary School Journal, 93(4), 373-397.

Ball, D. L., \& Friel, S. N. (1991). Implementing the "professional standards for teaching mathematics": What's all this talk about "discourse"? The Arithmetic Teacher, 39(3), 44-48. Retrieved from http://www.jstor.org/stable/41195113

Borasi, R. (1994). Capitalizing on errors as "springboards for inquiry": A teaching experiment. Journal for Research in Mathematics Education, 25(2), 166-208. Retrieved from http://www.jstor.org/stable/749507

Downing, D. (2009). Dictionary of Mathematics Terms. Barron's Educational Series, Inc. (Third Edit). New York: Barron's Educational Series, Inc. https://doi.org/10.2307/ 3614426

Imelda. (2018). Analisis Kesulitan Mahasiswa dalam Menyelesaikan Soal Pemecahan Masalah Pada Mata Kuliah Aljabar dan Trigonometri. Journal of Mathematics Education and Science, 4(1), $49-56$.

Jaelani, A. (2017). Kesalahan jawaban tes trigonometri mahasiswa pendidikan matematika semester pertama. Journal of Mathematics Education, 3(2), 1-13.

Kalyuga, S. (2009). Cognitive load factors in instructional design for advanced learners. New York: Nova Science Publishers, Inc.

Lial, M. L., Hornsby, J., Schneider, D. I., \& Daniels, C. J. (2016). Trigonometry (11th ed.). New York: Pearson.

Muthukrishnan, P., Kee, M. S., \& Sidhu, G. K. (2019). Addition error patterns among the preschool children. International Journal of Instruction, 12(2), 115-132. https://doi.org/10.29333/iji.2019.1228a

Nabie, M. J., Akayuure, P., Ibrahim-Bariham, U. A., \& Sofo, S. (2018). Trigonometric concepts: Preservice teachers' perceptions and knowledge. Journal on Mathematics Education, 9(2), 169182. https://doi.org/10.22342/jme.9.2.5261.169-182

Nejad, M. J. (2016). Undergraduate Students' Perception of Transformation of Sinusoidal Functions. In M. B. Wood, E. E. Turner, M. Civil, \& J. A. Eli (Eds.), Proceedings of the 38th annual 
meeting of the North American Chapter of the International Group for the Psychology of Mathematics Education (pp. 589-596). Tucson, AZ: The University of Arizona.

Oktaviani, M. (2017). Analysis of students' error in doing mathematics problem on proportion. In Proceedings ofthe 2nd Asian Education Symposium (AES 2017) (pp. 172-177). https://doi.org/10.5220/0007300601720177

Setiawan, Y. E. (2020a). Analisis Kemampuan Siswa dalam Pembuktian Kesebangunan Dua Segitiga. Al-Khwarizmi: Jurnal Pendidikan Matematika Dan Ilmu Pengetahuan Alam, 8(1), 23-38. https://doi.org/http://dx.doi.org/10.24256/jpmipa.v8i1.80

Setiawan, Y. E. (2020b). Analisis Kesalahan Siswa dalam Menggeneralisasi Pola Linier. Jurnal Nasional Pendidikan Matematika, 4(2), 180-194. https://doi.org/http://dx. doi.org/10.33603/jnpm.v4i2.3386

Setiawan, Y. E. (2020c). Analisis Kesalahan Siswa dalam Menilai Kebenaran Suatu Pernyataan. Jurnal Didaktik Matematika, 7(1), 13-31. https://doi.org/10.24815/ jdm.v7i1.14495

Setiawan, Y. E. (2020d). Proses Berpikir Siswa dalam Memperbaiki Kesalahan Generalisasi Pola Linier. Mosharafa: Jurnal Pendidikan Matematika, 9(3), 371-382. https://doi.org/https://doi.org/10.31980/mosharafa.v9i3.751

Setiawan, Y. E. (2020e). Sistem Pendukung Pengambilan Keputusan Rekrutmen Guru Menggunakan Logika Fuzzy Tahani. Barekeng: Jurnal Ilmu Matematika Dan Terapan, 14(2), 259-272. https://doi.org/https://doi.org/10.30598/barekengvol14iss2pp259-272

Setiawan, Y. E. (2020f). The Thinking Process of Students Using Trial and Error Strategies in Generalizing Linear Patterns. Numerical: Jurnal Matematika Dan Pendidikan Matematika, 4(1), 1-12. https://doi.org/https://doi.org/10.25217/numerical.v4i1.839

Setiawan, Y. E. (2021). Analisis Kesalahan Mahasiswa Semester Pertama dalam Menentukan Nilai Fungsi Trigonometri Sudut Istimewa. Supremum Journal of Mathematics Education, 5(1), 110121. https://doi.org/https://doi.org/10.35706/sjme.v5i1.4531

Setiawan, Y. E., \& Mustangin. (2020a). Kepraktisan Model Pembelajaran IDEA (Issue, Discussion, Establish, and Apply) dalam Pembelajaran Matematika. Aksioma: Jurnal Program Studi Pendidikan Matematika, 9(3), 776-788. https://doi.org/https://doi.org/ 10.24127/ajpm.v9i3.2917 Setiawan, Y. E., \& Mustangin. (2020b). Validitas Model Pembelajaran IDEA ( Issue, Discussion, Establish, and Apply) untuk Meningkatkan Pemahaman Konsep. Jurnal Penelitian Pendidikan Dan Pengajaran Matematika, 6(1), 53-60. https://doi.org/https:// doi.org/10.37058/jp3m.v6i1.1432

Setiawan, Y. E., Purwanto, Parta, I. N., \& Sisworo. (2020). Generalization Strategy of Linear Patterns From Field-Dependent Cognitive Style. Journal on Mathematics Education, 11(1), 77-94. https://doi.org/http://doi.org/10.22342/jme.11.1.9134.77-94

Setiawan, Y. E., \& Syaifuddin. (2020). Peningkatan Kompetensi Profesionalitas Guru Melalui Pelatihan Desain Pembelajaran Peta Konsep. Jurnal Pengabdian Kepada Masyarakat, 26(3), 
Analisis Kesalahan Mahasiswa Semester Pertama Dalam Menentukan Nilai Fungsi Trigonometri Sudut Kuadran, Yayan Eryk Setiawan

148-153. https://doi.org/http://dx.doi.org/10.24114/jpkm.v26i3. 16377

Webb, N. M., \& Mastergeorge, A. M. (2003). The development of students' helping behavior and learning in peer-directed small groups. Cognition and Instruction, 21(4), 361-428. https://doi.org/10.1207/s1532690xci2104

Wongapiwatkul, P., \& Laosinchai, P. (2011). Enhancing Conceptual Understanding of Trigonometry Using Earth Geometry and The Great Circle. Australian Senior, 25(1), 54-64. 